Original Research Article

\title{
Medication waste disposal practices among patients attending selected out patient departments in a tertiary care institution: a cross sectional survey
}

\author{
Vipula R. Bataduwaarachchi*, Rameshkumar Thevarajah, Chamari L. Weeraratne
}

Department of Pharmacology, Faculty of Medicine, University of Colombo, Shri Lanka

Received: 05 February 2018 Accepted: 07 March 2018

*Correspondence to:

Dr. Vipula R.

Bataduwaarachchi,

Email: vipbat7@yahoo.com

Copyright: (C) the author(s), publisher and licensee Medip Academy. This is an openaccess article distributed under the terms of the Creative Commons Attribution NonCommercial License, which permits unrestricted noncommercial use, distribution, and reproduction in any medium, provided the original work is properly cited.

\begin{abstract}
Background: Medication waste has major implications on human and animal health, environmental safety and the health economy. Low and middle income countries have paid less attention to proper medication waste disposal at household and community level. This is the first baseline assessment on medication waste disposal practices among the general public in Sri Lanka.

Methods: This was a descriptive, cross-sectional survey, conducted via face to face interviews using a structured questionnaire among selected outpatient clinics at the National Hospital of Sri Lanka. A non-probability sampling technique was used to achieve a representative sample from each clinic. The data collectors were trained prior to administering the questionnaire. Data was presented as descriptive statistics using percentages. Chi-square test was used to find associations.

Results: From the total number of participants $(n=200)$ majority were females $135(67.5 \%)$. Majority of the participants $(78 \%)$ stated that they have unused medicines at home. Among them, tablet form was the commonest $(78 \%)$ followed by topical preparations (49\%). Commonest reason for having unused medicines at home were self-discontinuation as illness resolved $(57.5 \%)$. There was a significant difference between the knowledge and practices when disposing tablet form $(<0.001)$, syrups $(0.002)$, topical preparations $(0.04)$ and sharps $(<0.001)$. Majority (23\%) discarded sharp to rubbish bins. Rubbish bin was the commonest mode of disposal for all dosage forms as well as devices.

Conclusions: In this sample majority had unused medicines at home which was compatible with the pattern seen in other countries and need proper attention.
\end{abstract}

Keywords: Medication waste, Pharmaceutical waste disposal

\section{INTRODUCTION}

Health care waste is defined as the waste generated by health care establishments, medical research facilities, laboratories and from minor sources such as health care undertaken at households. Of them, pharmaceutical waste or medication waste includes expired, unused, spilt, and contaminated pharmaceutical products and the items used in the handling of pharmaceuticals. ${ }^{1}$ Medication waste has major implications on human and animal health, environmental safety and the health economy. Pharmaceutical products in the environment threaten wildlife with continuous exposure even at low concentrations. Environmental monitoring has detected a number of commonly used medicines present in some environments at levels high enough to harm aquatic organisms. ${ }^{2}$ However, regular environmental monitoring is not feasible specially in developing countries. Presence of antibiotics in the environment cause bactericide and bacteriostatic actions as well as development of antibiotic resistance. $^{3}$

According to WHO recommendations, strategies to dispose large quantities of pharmaceutical waste are 
encapsulation and burial in a sanitary landfill or incineration in kilns equipped with pollution control devices. Dilution and sewer discharge is recommended only for relatively harmless liquids. ${ }^{1}$ However, each country needs a customised approach when handling medication waste based on the background situation. According to a study done in Ireland, $88 \%(n=398)$ of the participants had unused medicines at home and $72 \%$ had disposed medicines inappropriately despite having a programme to collect unwanted medicines. ${ }^{4}$ Data from the developing countries on medication waste disposal practices is lacking. According to a study conducted in Afghanistan, $95.3 \% \quad(n=301)$ of the participants had unused medicines at home and $77.7 \%$ of them disposed in the trash. The NMP of Afghanistan allocates $1 \%$ of the cost of all medicines for the pharmaceutical waste management. ${ }^{5}$ From a survey done in the US, one third of prescriptions were not used by patients and the national projected costs due to unused medicines ranged between 2.4 - 5.4 billion USD. ${ }^{6}$ A research report published in 2010 in England has estimated that the national figure for pharmaceutical waste was $£ 300$ Million. ${ }^{7}$ These estimates are of a greater importance to the developing countries with low annual health care expenditures. According to Sri Lanka National Health Accounts in 2013, expenditure on pharmaceuticals was $23.6 \%$ of the annual total health expenditure. $^{8}$

In a short survey done in 18 public hospitals in Colombo, Sri Lanka, pharmaceutical waste was not categorised as waste. Therefore, they did not enter the general waste streams since expired pharmaceutical products were returned to the manufacturing companies from hospitals and pharmacies. ${ }^{9}$

However, this survey has not assessed medication waste disposal practices among the general public. Although Sri Lanka has a much better health care delivery system compared to some countries in the region, with health indicators comparative to developed countries, there is no properly established medication waste disposal programme integrated with it. This study is the first baseline assessment on medication waste disposal practices among the general public in Sri Lanka.

\section{METHODS}

This was a descriptive, cross-sectional survey, conducted through face to face interviews using a structured questionnaire. This was conducted among selected outpatient clinics at the National Hospital of Sri Lanka.

\section{Study population}

The study population was of either gender, above the age of 18 years, who were attending outpatient clinics, regardless of ethnicity or employment status. Medical, surgical and dermatology clinics were selected to represent patients using different formulations of medicines.

\section{Sampling/sample size}

A non-probability sampling technique (convenience method) was used to achieve a representative sample from each clinic. A total of 200 participants participated in the study: 50 from each medical, surgical, dermatology clinic and the general OPD.

\section{Study instrument}

A comprehensive literature review was done to identify the parameters to be assessed in the questionnaire which consisted of five sections., ${ }^{40-13}$ Section 1 was about respondent's demographic information including gender, age, ethnicity, level of education, monthly income, etc. Section 2 included questions on the types of unused/ expired medications at home, reasons for having unused medicines, storage of medicines, prior advice received about safe disposal and sources of such information and attitude on safe disposal. Section 3 and 4 included questions on their knowledge and practices regarding the disposal of different dosage forms of medicines. Section 5 assessed their difficulties and suggestions on medication waste disposal. Most of the questions were close-ended, while selected questions gave the option to the respondents to record further explanations and their own opinion. The questionnaire was adapted to the local context and translated into local languages and back translated into English to avoid any misinterpretations. For face and content validity, the questionnaire was reviewed by experts and pretested on 15 respondents. Following the pilot testing, minor changes were made.

\section{Data collection method}

The data collectors were trained and instructed to explain the purpose of the study to their potential respondents prior to administering the questionnaire. Participation in the survey was voluntary. The questionnaire was provided in two languages (Sinhala and Tamil). Face-to-face interviews were conducted to fill up questionnaires at the above mentioned clinics during the month of April 2017 until the expected sample was collected.

\section{Ethical considerations}

Informed written consent was obtained from all the respondents before the start of the study. Participation in this study was voluntary. Participants identity was kept confidential. The permission was obtained from the director of the National Hospital Sri Lanka and the consultants of relevant clinics.

\section{Data analysis}

All completed questionnaires were double checked for accuracy and the collected data were fed into a SPSS database. The cleaned data set was analysed using the SPSS version 21. Descriptive statistics (descriptive, crosstab and chi-square test) was used. 


\section{RESULTS}

From the total number of participants $(n=200)$ majority were females 135 (67.5\%). Participants mean age was 49.8 years ( $\mathrm{SD} \pm 14.3)$. Major ethnic group was Sinhalese (53\%) followed by Tamil and Sri Lankan Moor which was compatible with the composition of the general population. Only $4 \%$ of the participants were illiterate and the majority $(61 \%)$ received a monthly income between 10,000-50,000 SLR (Table 1).

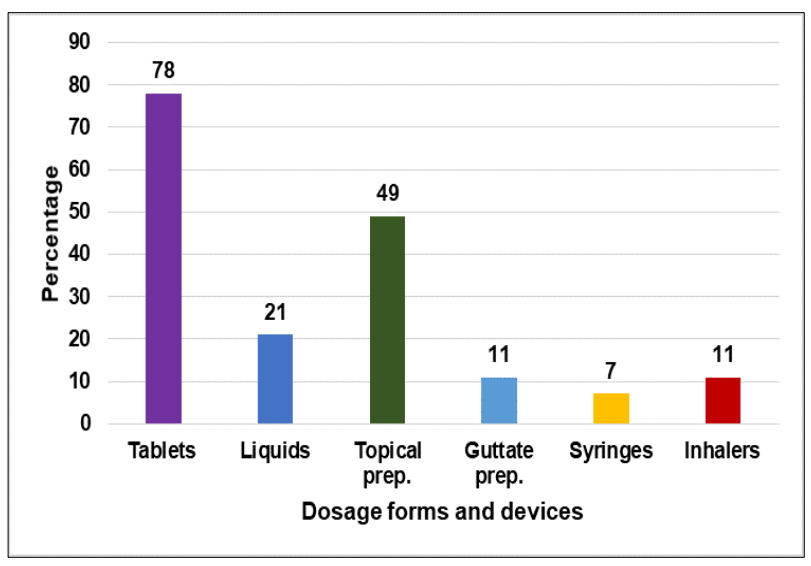

Figure 1: Percentage of unused dosage forms and device.
Table 1: Demographic characteristics of the participants.

\begin{tabular}{|c|c|c|c|}
\hline \multicolumn{2}{|c|}{$\begin{array}{l}\text { Demographic } \\
\text { characteristics }\end{array}$} & \multicolumn{2}{|c|}{$\begin{array}{l}\text { Number of responses } \\
n=200(\%)\end{array}$} \\
\hline \multirow{2}{*}{ Gender } & Men & 65 & 32.5 \\
\hline & Women & 135 & 67.5 \\
\hline \multirow{2}{*}{ Age } & $18-30$ & 28 & 14 \\
\hline & $31-50$ & 68 & 34 \\
\hline \multicolumn{2}{|c|}{51 above } & 104 & 52 \\
\hline \multicolumn{4}{|c|}{ Ethnicity } \\
\hline \multicolumn{2}{|c|}{ Sinhalese } & 106 & 53 \\
\hline \multicolumn{2}{|c|}{ Tamil } & 42 & 21 \\
\hline \multicolumn{2}{|c|}{ Sri Lankan Moor } & 33 & 16.5 \\
\hline \multicolumn{2}{|c|}{ Other } & 19 & 9.5 \\
\hline \multicolumn{4}{|c|}{ Educational level } \\
\hline \multicolumn{2}{|c|}{ Illiterate } & 4 & 2 \\
\hline \multicolumn{2}{|c|}{ Primary } & 141 & 70.5 \\
\hline \multicolumn{2}{|c|}{ Secondary } & 48 & 24 \\
\hline \multicolumn{2}{|c|}{ University } & 7 & 3.5 \\
\hline \multicolumn{4}{|c|}{ Monthly income (SLR) } \\
\hline \multicolumn{2}{|c|}{$<10,000$} & 54 & 27 \\
\hline \multicolumn{2}{|c|}{$10,000-50,000$} & 122 & 61 \\
\hline \multicolumn{2}{|c|}{$50,000-100,000$} & 22 & 11 \\
\hline \multicolumn{2}{|c|}{$>100,000$} & 2 & 1 \\
\hline
\end{tabular}

Table 2: Respondents' knowledge and practices regarding the disposal of medication waste.

\begin{tabular}{|c|c|c|c|}
\hline Stem response & & $\mathrm{n}=\mathbf{2 0 0}$ & $\%$ \\
\hline \multirow[t]{2}{*}{ Unused medicines present at home? } & Yes & 156 & 78 \\
\hline & No & 41 & 20.5 \\
\hline \multirow[t]{2}{*}{ Place of storage of unused medications? } & In a secured/locked place not reachable to children & 192 & 96 \\
\hline & In an open place reachable to children & 8 & 4 \\
\hline \multirow[t]{2}{*}{$\begin{array}{l}\text { Has received advice regarding safe disposal } \\
\text { practices of medications ever }\end{array}$} & Yes & 10 & 5 \\
\hline & No & 190 & 95 \\
\hline \multirow[t]{4}{*}{$\begin{array}{l}\text { If yes, the way participants have received that } \\
\text { information? }\end{array}$} & Doctor & 2 & 1 \\
\hline & Pharmacist & 2 & 1 \\
\hline & Electronic / printed media & 3 & 1.5 \\
\hline & Product information leaflet/ packaging of the medicine & 3 & 1.5 \\
\hline \multirow[t]{2}{*}{$\begin{array}{l}\text { believe that incorrect disposal methods could } \\
\text { lead to environmental and health hazards? }\end{array}$} & Yes & 135 & 67.5 \\
\hline & No & 65 & 32.5 \\
\hline \multirow[t]{8}{*}{$\begin{array}{l}\text { Reasons for having unused medications at } \\
\text { home? }\end{array}$} & Patient died & 4 & 2 \\
\hline & Change or discontinuation by the doctor & 21 & 10.5 \\
\hline & Self-discontinuation due to unpleasant side effects & 24 & 12 \\
\hline & $\begin{array}{l}\text { Self-discontinuation as the illness/ symptoms } \\
\text { improved/ resolved }\end{array}$ & 115 & 57.5 \\
\hline & Clear instructions not given by the doctor/ pharmacist & 7 & 3.5 \\
\hline & Prescribed and/or dispensed more than required & 49 & 24.5 \\
\hline & Reached the expiry date & 15 & 7.5 \\
\hline & Forgetfulness & 58 & 29 \\
\hline
\end{tabular}


Table 2: (Continue...)

\begin{tabular}{|c|c|c|c|}
\hline Stem response & & $\mathrm{n}=\mathbf{2 0 0}$ & $\%$ \\
\hline \multirow[t]{5}{*}{$\begin{array}{l}\text { Opinion on options for reducing medication } \\
\text { waste }\end{array}$} & Prescribe medications rationally & 87 & 43.5 \\
\hline & Dispense only as required & 106 & 53 \\
\hline & Give proper advices to consumer & 56 & 28 \\
\hline & Donate unexpired but unused medicines to friends & 17 & 8.5 \\
\hline & Collect by pharmacies & 12 & 6 \\
\hline \multirow[t]{4}{*}{$\begin{array}{l}\text { Best method for collection of unused } \\
\text { medicines for disposal }\end{array}$} & Return to pharmacy or hospital for disposal & 76 & 38 \\
\hline & Secured collection containers at local shopping malls & 40 & 20 \\
\hline & Collecting from homes by municipal authorities & 76 & 38 \\
\hline & Other & 4 & 2 \\
\hline
\end{tabular}

Table 3: Comparison of what they knew as the suitable methods for disposal of medicines and devices and their practices.

\begin{tabular}{|c|c|c|c|c|c|c|c|c|c|c|}
\hline $\begin{array}{l}\text { Dosage } \\
\text { form }\end{array}$ & & $\begin{array}{l}\text { To } \\
\text { rubbish- } \\
\text { bin }\end{array}$ & To sink & $\begin{array}{l}\text { Flushing } \\
\text { in toilet }\end{array}$ & $\begin{array}{l}\text { Taken } \\
\text { back }\end{array}$ & Burning & Burying & $\begin{array}{l}\text { Given to } \\
\text { a family } \\
\text { member }\end{array}$ & $\begin{array}{l}\text { Given to } \\
\text { another } \\
\text { person }\end{array}$ & $\mathbf{P}$ \\
\hline \multirow[t]{2}{*}{ Tablets } & Knowledge & $\begin{array}{l}114 \\
(57 \%)\end{array}$ & $10(5 \%)$ & $\begin{array}{l}19 \\
(9.5 \%)\end{array}$ & $\begin{array}{l}7 \\
(3.5 \%)\end{array}$ & $\begin{array}{l}28 \\
(14 \%)\end{array}$ & $\begin{array}{l}46 \\
(23 \%)\end{array}$ & $\begin{array}{l}15 \\
(7.5 \%)\end{array}$ & $1(0.5 \%)$ & \multirow{2}{*}{$<0.001$} \\
\hline & Practice & $\begin{array}{l}149 \\
(74.5 \%)\end{array}$ & $2(1 \%)$ & $9(4.5 \%)$ & 0 & $\begin{array}{l}19 \\
(9.5 \%)\end{array}$ & $\begin{array}{l}20 \\
(10 \%)\end{array}$ & $6(3 \%)$ & 0 & \\
\hline \multirow[t]{2}{*}{ Syrups } & Knowledge & $\begin{array}{l}43 \\
(21.5 \%)\end{array}$ & $\begin{array}{l}112 \\
(56 \%)\end{array}$ & $26(13 \%)$ & $4(2 \%)$ & $3(1.5 \%)$ & $\begin{array}{l}17 \\
(8.5 \%)\end{array}$ & $3(1.5 \%)$ & $2(1 \%)$ & \multirow{2}{*}{0.002} \\
\hline & Practice & $54(27 \%)$ & $\begin{array}{l}54 \\
(27 \%)\end{array}$ & $8(4 \%)$ & 0 & $3(1.5 \%)$ & $9(4.5 \%)$ & $3(1.5 \%)$ & 0 & \\
\hline \multirow[t]{2}{*}{ Topical } & Knowledge & $\begin{array}{l}125 \\
(62.5 \%)\end{array}$ & $2(1 \%)$ & $2(1 \%)$ & $4(2 \%)$ & $\begin{array}{l}20 \\
(10 \%)\end{array}$ & $\begin{array}{l}40 \\
(20 \%)\end{array}$ & $\begin{array}{l}15 \\
(7.5 \%)\end{array}$ & $2(1 \%)$ & \multirow{2}{*}{0.04} \\
\hline & Practice & $\begin{array}{l}114 \\
(57 \%)\end{array}$ & 0 & $1(0.5 \%)$ & $\begin{array}{l}1 \\
(0.5 \%)\end{array}$ & $\begin{array}{l}19 \\
(9.5 \%)\end{array}$ & $14(7 \%)$ & $7(3.5 \%)$ & 0 & \\
\hline \multirow[t]{2}{*}{$\begin{array}{l}\text { Guttate } \\
*\end{array}$} & Knowledge & $\begin{array}{l}108 \\
(54 \%)\end{array}$ & $\begin{array}{l}26 \\
(13 \%)\end{array}$ & $9(4.5 \%)$ & $4(2 \%)$ & $\begin{array}{l}15 \\
(7.5 \%)\end{array}$ & $\begin{array}{l}27 \\
(13.5 \%)\end{array}$ & $6(3 \%)$ & $2(1 \%)$ & \multirow{2}{*}{0.27} \\
\hline & Practice & $\begin{array}{l}67 \\
(33.5 \%)\end{array}$ & $8(4 \%)$ & $2(1 \%)$ & $\begin{array}{l}1 \\
(0.5 \%)\end{array}$ & $8(4 \%)$ & $10(5 \%)$ & 0 & $1(0.5 \%)$ & \\
\hline \multirow[t]{2}{*}{ Sharps } & Knowledge & $\begin{array}{l}85 \\
(42.5 \%)\end{array}$ & $\begin{array}{l}52 \\
(26 \%)\end{array}$ & $\begin{array}{l}15 \\
(7.5 \%)\end{array}$ & $6(3 \%)$ & $\begin{array}{l}13 \\
(6.5 \%)\end{array}$ & $\begin{array}{l}75 \\
(37.5 \%)\end{array}$ & 0 & $1(0.5 \%)$ & \multirow[t]{2}{*}{$<0.001$} \\
\hline & Practice & $46(23 \%)$ & 0 & $5(2.5 \%)$ & $2(1 \%)$ & $12(6 \%)$ & $14(7 \%)$ & 0 & 0 & \\
\hline \multirow[t]{2}{*}{ Inhalers } & Knowledge & $\begin{array}{l}123 \\
(61.5 \%)\end{array}$ & $1(5 \%)$ & $3(1.5 \%)$ & $6(3 \%)$ & $\begin{array}{l}15 \\
(7.5 \%)\end{array}$ & $\begin{array}{l}40 \\
(20 \%)\end{array}$ & $1(0.5 \%)$ & $1(0.5 \%)$ & \multirow{2}{*}{0.26} \\
\hline & Practice & $60(30 \%)$ & $\begin{array}{l}1 \\
(0.5 \%)\end{array}$ & $3(1.5 \%)$ & $\begin{array}{l}1 \\
(0.5 \%)\end{array}$ & $5(2.5 \%)$ & $9(4.5 \%)$ & 0 & $2(1 \%)$ & \\
\hline
\end{tabular}

Majority of the participants $(78 \%)$ stated that they have unused medicines at home. Among them, tablet form was the commonest $(78 \%)$ followed by topical preparations (49\%) (Figure 1). Commonest reasons for having unused medicines at home were self-discontinuation as illness resolved (57.5\%), forgetfulness $(29 \%)$ and being prescribed more than required $(24.5 \%)$. Of the participants, $192(96 \%)$ stored medicines in a secure place not reachable to children. Only $42(21 \%)$ of the participants knew the names of the medicines they were prescribed. Only $8(4 \%)$ had received advice regarding disposal of medicines previously. Majority $(67.5 \%)$ of the participants believed that the incorrect disposal leads to environmental hazard. Rational prescribing (43.5\%) and purchase of medicines only as required (53\%) were perceived as the best methods to reduce medication by the participants. Majority were willing to return unused medicines to pharmacies $(38 \%)$ or municipal authorities (38\%) (Table 2). Majority $(85.5 \%)$ of the participants discarded the medications without any prior procedures. Of them $15.5 \%$ discarded after crushing tablets and $7.5 \%$ diluted the drug before discarding. The need for national scheme for disposal of unused domestic medicines was perceived as a requirement by $93 \%$. While $81.5 \%$ of the participants were willing to participate in a medication waste disposal programme, $12 \%$ were inconclusive and $6.5 \%$ were unwilling (Table 2). 
Table 4: Comparison of selected characteristics on medication waste disposal between different populations.

\begin{tabular}{|c|c|c|c|c|c|c|c|c|c|}
\hline \multicolumn{2}{|l|}{ Country } & US & Ireland & $\begin{array}{l}\text { New } \\
\text { Zealand }\end{array}$ & Afghanistan & Jordan & Serbia & Kuwait & $\begin{array}{l}\text { Sri } \\
\text { Lanka }\end{array}$ \\
\hline \multicolumn{2}{|l|}{$\begin{array}{l}\text { Study } \\
\text { (year) }\end{array}$} & $\begin{array}{l}\text { Law, } \\
\text { Anandi } \\
\text { V }\end{array}$ & $\begin{array}{l}\text { Vellinga, } \\
\text { Akke }\end{array}$ & $\begin{array}{l}\text { Braund, } \\
\text { Rhiannon }\end{array}$ & $\begin{array}{l}\text { Basheer, } \\
\text { Mohammad }\end{array}$ & $\begin{array}{l}\text { Sayer } \\
\text { Al- } \\
\text { Azzam }\end{array}$ & $\begin{array}{l}\text { Milica } \\
\text { Paut } \\
\text { Kusturica }\end{array}$ & $\begin{array}{l}\text { Eman A. } \\
\text { Abahussain }\end{array}$ & $\begin{array}{l}\text { This } \\
\text { study }\end{array}$ \\
\hline \multicolumn{2}{|l|}{$\begin{array}{l}\text { Participants } \\
\text { (n) }\end{array}$} & 306 & 398 & 452 & 301 & 435 & 383 & 300 & 200 \\
\hline \multicolumn{2}{|l|}{$\begin{array}{l}\text { Unused } \\
\text { medicines } \\
(\%)\end{array}$} & 66 & 88 & 62 & 95.3 & 34.7 & 44.4 & 95.70 & 78 \\
\hline & & & & $(\mathrm{n}=1028)^{*}$ & & & & & \\
\hline \multirow{12}{*}{$\begin{array}{l}\text { Reasons } \\
\text { for unused } \\
\text { medicine } \\
(\%)\end{array}$} & Condition improved & 42.4 & 31 & 29.8 & - & - & - & - & 57.5 \\
\hline & Forgetfulness & 5.8 & - & - & - & - & - & - & 29 \\
\hline & Side effects & 6.5 & 13 & 14.7 & - & - & - & - & 12 \\
\hline & Change of medicines & - & 11 & 16.5 & - & - & - & 48.9 & 10.5 \\
\hline & Excess quantity & - & - & 16.3 & - & - & - & 9.8 & 24.5 \\
\hline & Expired & - & - & 15.0 & - & - & - & 10.6 & 7.5 \\
\hline & $\begin{array}{l}\text { Unsure why } \\
\text { prescribed }\end{array}$ & - & - & 2.5 & - & - & - & - & - \\
\hline & Inconvenience & - & - & 2.1 & - & - & - & - & - \\
\hline & Unclear instructions & - & - & 1.7 & - & - & - & - & 3.5 \\
\hline & Patient deceased & - & - & 2.1 & - & - & - & - & 2 \\
\hline & Self-discontinuation & - & - & - & & - & - & 25.8 & 12 \\
\hline & & & & $(n=1028)^{*}$ & & & & & \\
\hline \multirow{5}{*}{$\begin{array}{l}\text { Why kept } \\
\text { them at } \\
\text { home }(\%)\end{array}$} & $\begin{array}{l}\text { If needed for later } \\
\text { use }\end{array}$ & - & 57 & 21.4 & - & - & - & - & 70 \\
\hline & $\begin{array}{l}\text { Don't want to waste } \\
\text { them }\end{array}$ & - & 20 & 9.2 & - & - & - & - & 13.5 \\
\hline & $\begin{array}{l}\text { Not sure how to } \\
\text { dispose them }\end{array}$ & - & 17 & 9.7 & - & - & - & - & 3 \\
\hline & $\begin{array}{l}\text { To give to other } \\
\text { people if needed }\end{array}$ & - & 5 & 0.9 & - & - & - & - & 8.5 \\
\hline & Do not keep them & - & - & 11.6 & - & - & - & - & 20.5 \\
\hline \multirow{5}{*}{$\begin{array}{l}\text { Type of } \\
\text { medicines/ } \\
\text { device }(\%)\end{array}$} & Tablets & - & - & - & - & - & 64.7 & 66.2 & 78 \\
\hline & Topical preparations & - & - & - & - & - & 21.9 & 35.2 & 49 \\
\hline & Drops, syrups & - & - & - & - & - & 11.9 & 51.6 & 33 \\
\hline & Inhalers & - & - & - & - & - & 1.5 & 10.5 & 11 \\
\hline & Injections & - & - & - & - & - & - & 9.1 & 0 \\
\hline & & & $(n=281)$ & & & & & & \\
\hline \multirow{10}{*}{$\begin{array}{l}\text { Methods of } \\
\text { disposal } \\
(\%)\end{array}$} & Throwing in trash & 63 & 51 & - & 77.7 & - & 82.8 & 76.5 & 75.4 \\
\hline & $\begin{array}{l}\text { Flushing down the } \\
\text { toilet }\end{array}$ & 26 & 14 & - & 12 & - & 2.9 & 11.2 & 1 \\
\hline & Sink & 4.3 & 29 & - & & - & & & 4.5 \\
\hline & Appropriate disposal & 13 & - & - & - & - & 4.4 & 11.9 & 0 \\
\hline & Store & 17.4 & - & - & - & - & 0.8 & - & - \\
\hline & Burning & - & - & - & - & - & 1.8 & - & 9.5 \\
\hline & Burying & - & - & - & - & - & - & - & 10 \\
\hline & $\begin{array}{l}\text { Always use till the } \\
\text { end }\end{array}$ & - & - & - & - & - & 7.3 & - & - \\
\hline & $\begin{array}{l}\text { Give to family } \\
\text { member }\end{array}$ & - & - & - & - & - & - & - & 3 \\
\hline & $\begin{array}{l}\text { Give to another } \\
\text { person }\end{array}$ & - & - & - & - & - & - & 8.5 & 0 \\
\hline \multirow{8}{*}{$\begin{array}{l}\text { Storage } \\
\text { place }(\%)\end{array}$} & Bathroom & 59 & 13 & 29 & - & - & - & - & - \\
\hline & Kitchen & 35 & 67 & 48 & - & - & - & - & - \\
\hline & Bedroom & 24 & 19 & 13 & - & 40.2 & - & - & - \\
\hline & Refrigerator & 14 & - & - & - & 46.2 & - & - & - \\
\hline & Dining room & - & - & - & - & 94.7 & - & - & - \\
\hline & First Aid box & - & - & - & - & 46.2 & - & - & - \\
\hline & Secured place & - & - & - & - & - & - & - & 96 \\
\hline & $\begin{array}{l}\text { Reachable to } \\
\text { children }\end{array}$ & - & - & - & - & - & - & - & 4 \\
\hline
\end{tabular}


There was a significant difference between the knowledge and practices when disposing tablet form $(<0.001)$, syrups (0.002), topical preparations $(0.04)$ and sharps $(<0.001)$. Almost always percentage of participants who knew a method of disposal for particular dosage form was higher than the percentage who actually practiced the same except when discarding tablets and liquids to rubbish bins. Majority (23\%) discarded sharp to rubbish bins. Rubbish bin was the commonest mode of disposal for all dosage forms as well as devices (Table 3).

Our data shows a similar pattern to other populations with regard to most practices except for selecting the commonest storage place for unused medicines. Data shows a wide variation of the storage place ranging from the bathroom (US study), the dining room (Jordan study), the kitchen (Ireland and New Zealand studies) to a secured place not reachable to children in this study. ${ }^{4-6,10,11,14,15}$ Underlying reasons for this observation was not assessed (Table 4).

\section{DISCUSSION}

In Sri Lanka there is no established policy or a system for medication waste disposal. Health care delivery is mainly done by the free state sector hospital network. This is the first Sri Lankan study to assess the knowledge and practices regarding medication waste disposal among the general public.

In this sample majority had unused medicines at home. It was compatible with the pattern seen in other countries. Main reason for having unused medicines at homes was self-discontinuation as the symptoms resolved. Therefore, poor compliance seems to play a role in unused medicines. Therefore, improving the compliance is mandatory secondary to an established system. Main method of disposal was to throw them in the rubbish bin which has a higher risk of environment pollution risking animal and human health. ${ }^{16}$ Due to high population density in urban and suburban area, risk is increased by several folds. Authors suggest that medication waste disposal programme need to be started from the highly populated areas first to be more efficient.

Importantly, majority did not know the names and types of the medicines they used. This is a significate barrier to implementing successful medication waste disposal practices as people need to sort medicine to follow the correct practice. ${ }^{17}$ Therefore, we suggest that a more institution centred approach is needed than a patient centred programme where the sorting of medicine can be done later and may be even reused if not expired. Participants had given controversial responses on handing over unused medicines to pharmacies. Secured collection containers at local shopping malls will be a more practical way and it will save time in a busy setting. Majority of our participants stored medicines in a secure place compared to the participants in studies conducted in other countries.
This indicates that they have better knowledge and awareness regarding this matter.

There was a significant difference in the knowledge of medication waste disposal method versus the actual practice for disposing the same dosage form. Lack of disposal programme might have been the reason for this discrepancy and need to be reassessed in a pilot programme. The European Union has issued a directive in 2004, stating that the member states shall ensure that appropriate collection systems are to be in place for medicinal products that are unused or have expired. ${ }^{18}$ In 2006, EMA introduced environmental risk assessment for new medicinal products requesting authorisation. ${ }^{19}$ In the South-East Asia region, India and Indonesia have EPR for pharmaceuticals in their legislations. Increasing elderly population and increased medicalisation of lives makes medication waste disposal an important area to be focused. In Sri Lanka, Ministry of Health and the CEA are responsible for medical waste management. ${ }^{20} \mathrm{~A}$ clear policy and action plan on medication waste disposal should be established in Sri Lanka and in the region.

Higher literacy level and higher rates of willingness to participate among people are the positive factors to establish a medication waste management system. Wastage of medicines is a great economic burden to low and middle-income nations having an aging population. Integration of a medical waste disposal system will allow reuse of certain amounts of unexpired medicines and it will reduce the burden to some extent. However, intermediate quality assurance steps may be needed, and this can be assessed in a pilot project. On the other hand, general measures such as prescription and dispense of the minimum requirement of medicines will reduce unused medicines at households. We suggest a simple sticker on the packings regarding the method of disposal to close the knowledge gap effectively. Significantly low numbers of participants have received knowledge on correct practices of medication disposal. We suggest education using mass media to reach a wide audience faster and to improve the overall participation.

Authors have planned to conduct a pilot study on a medication waste disposal programme with several rounds of feedback before designing a system to Sri Lanka.

\section{ACKNOWLEDGEMENTS}

Authors would like to acknowledge the help from director of the National Hospital of Sri Lanka and the consultants of the relevant clinics.

Funding: No funding sources Conflict of interest: None declared

Ethical approval: The study was approved by the ERC of the Faculty of Medicine, University of Colombo, Shri Lanka 


\section{REFERENCES}

1. World Health Organisation. Safe management of wastes from health-care activities, 2014. Available at: http://www.who.int/water_sanitation_health/publicati ons/wastemanag/en/. Accessed 27 Nov 2017.

2. Natural Resources Defense Council. Dosed Without Prescription: Preventing Pharmaceutical Contamination of Our Nation's Drinking Water, 2010. Available at: https://www.nrdc.org/resources/dosedwithout-prescription-preventing-pharmaceuticalcontamination-our-nations-drinking. Accessed 29 Nov 2017.

3. Grenni P, Ancona V, Barra Caracciolo A. Ecological effects of antibiotics on natural ecosystems: A review. Microchemical Journal. 2018;136:25-39.

4. Vellinga A, Cormican S, Driscoll J, Furey M, O’Sullivan M, Cormican M. Public practice regarding disposal of unused medicines in Ireland. Sci. Total Environ. 2014;478:98-102.

5. Ahmed A, Mushtaq N, Tariq M, Durrani M, Akhtar S, Arif M, Yasmeen G. Disposal practices of unused and expired pharmaceuticals in Karachi and their impact on health and environment. JUMDC. 2013;2007(4):2.

6. Law AV, Sakharkar P, Zargarzadeh A, Tai BW, Hess $\mathrm{K}$, Hata M, et al. Taking stock of medication wastage: Unused medications in US households. Research in Social and Administrative Pharmacy. 2015 Jul 1;11(4):571-8.

7. University College of London. Evaluation of the scale, causes and costs of waste medicines. Report of DH funded national project, 2010. Available at: http://discovery.ucl.ac.uk/1350234/. Accessed 29 Nov 2017.

8. Ministry of Health. Sri Lanka National Health Accounts, 2013. Available at: http://www.health.gov.lk/enWeb/publication/NHA/Sr i Lanka National Health Accounts 2013.pdf. Accessed 27 Nov 2017.

9. Bundunee L, Athapattu C, Masafumi T. Waste Management Practices of Government Hospitals in Colombo, Sri Lanka. Int. J. Waste Resour. 2015;5:178.

10. Abahussain EA, Ball DE, Matowe WC. Practice and opinion towards disposal of unused medication in Kuwait. Med. Princ. Pract. 2006;15:352-7.

11. Jāmi'ah al-Urdunīyah. Imādat al-Bahth al-'Ilmī. S, Khader Y, Rawashdeh S, Hijazi S. An assessment of the extent of medication wastage among families in Jordan. Jordan J. Pharm. Sci. 2008;5(1):65-73.
12. Braund R, Peake BM, Shieffelbien L. Disposal practices for unused medications in New Zealand. Environ. Int. 2009;35:952-5.

13. Sonowal S, Desai C, Kapadia JD, Desai MK. A Survey of Knowledge, Attitude, and Practice of Consumers at a Tertiary Care Hospital Regarding the Disposal of Unused Medicines. J. basic Clin. Pharm. 2016;8:4-7.

14. Bashaar M, Thawani V, Hassali MA, Saleem F. Disposal practices of unused and expired pharmaceuticals among general public in Kabul. BMC Public Health. 2017;17:45.

15. Kusturica PM, Tomas A, Tomic Z, Bukumiric D, Corac A, Horvat O, et al. Analysis of expired medications in Serbian households. Zdr. Varst. 2016;55:195-201.

16. Boxall ABA. The environmental side effects of medication. EMBO Rep. 2004;5:1110-6.

17. World Health Organisation. Guidelines for Safe Disposal of Unwanted Pharmaceuticals in and after Emergencies Ordering Information Guidelines for the Safe Disposal of Unwanted Pharmaceuticals in and after Emergencies Interagency Guidelines, 1999. Available at: http://www.who.int/water_sanitation_health/medical waste/unwantpharm.pdf. Accessed 27 Nov 2017.

18. Persson M, Sabelström E, Gunnarsson B. Handling of unused prescription drugs--knowledge, behaviour and attitude among Swedish people. Environ. Int. 2009;35:771-4.

19. European Medicines Agency. Guideline on the environmental risk assessment of medicinal products for human use, 2006. Available at: http://www.emea.eu.int. Accessed 27 Nov 2017.

20. World Health House Indraprastha Estate Mahatma Gandhi Marg New Delhi, India Report on health-care waste management status in countries of the SouthEast Asia Region, 2017. Available at: http://apps.searo.who.int/PDS_DOCS/B5353.pdf. Accessed 27 Nov 2017.

Cite this article as: Bataduwaarachchi VR, Thevarajah R, Weeraratne CL. Medication waste disposal practices among patients attending selected out patient departments in a tertiary care institution: a cross sectional survey. Int J Basic Clin Pharmacol 2018;7:888-94. 